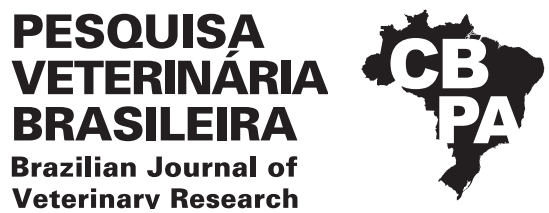

Pesq. Vet. Bras. 41:e06685, 2021 DOI: $10.1590 / 1678-5150-P V B-6685$

Original Article

Veterinarv Research

ISSN 0100-736X (Print)

ISSN 1678-5150 (Online)

\title{
Wooden breast and white striping: comparative occurrence in three poultry companies ${ }^{1}$
}

\author{
Sabrina T. Fraga ${ }^{2}$, Fátima R.F. Jaenisch ${ }^{3}$, Jane O. Peixoto ${ }^{3}$, Arlei Coldebella ${ }^{3}$ (D), \\ Karen A. Borges ${ }^{4 *}(\mathbb{D})$, Thales Q. Furian ${ }^{4}$ (D) Elci L. Dickel ${ }^{2}$ (D) and Luciana R. dos Santos ${ }^{2}$
}

\begin{abstract}
Fraga S.T., Jaenisch F.R.F., Peixoto J.O, Coldebella A., Borges K.A., Furian T.Q., Dickel E.L. \& dos Santos L.R. 2021. Wooden breast and white striping: occurrence in three poultry companies. Pesquisa Veterinária Brasileira 41:e06685, 2021. Faculdade de Agronomia e Medicina Veterinária, Universidade de Passo Fundo, Av. Brasil Leste 285, São José, Passo Fundo, RS 99052-900, Brazil. E-mail: karen.borges@ufrgs.br

To increase the amount of meat produced, researchers have promoted intensive genetic selection for growth rate and muscling and have improved nutrition and management conditions. However, there has been an increase in the number of reports of breast muscle myopathies observed in poultry processing plants, including white striping (WS) and wooden breast (WB). This study aimed to evaluate and to compare the occurrence of WS and WB myopathies in three poultry processing plants and to perform an anatomopathological characterization, including macroscopic and microscopic analyses. A total of 408,334 carcasses were condemned or downgraded due to the presence of WB or WS, which represents $0.73 \%$ of the total number of slaughtered animals during the evaluated period. WB was more frequent than WS, but the occurrence of each myopathy varied significantly according to each establishment. WB was more frequent in the establishment which includes only male flocks, an average age of 45 days, and an average live weight of $2775 \mathrm{~g}$ (B). WS was more frequent in establishment with male, female and mixed flocks, average ages ranging from 41 to 44 days, and average live weight $1731 \mathrm{~g}-2830 \mathrm{~g}(\mathrm{~A})$. It is probably related with specific condition of each poultry company, including genetics, age, nutrition and management conditions. Macroscopically, WB and WS lesions are characterized by hypertrophy and stiffness of the pectoralis major muscle. Under microscopy, the myopathies showed similarities regarding the detected histological abnormalities, characterized by a process of myodegeneration, although the connective tissue infiltrate was more severe in the breasts with WB than in those with WS myopathy. The results found in this study demonstrate that the rates of condemnation for these myopathies are high, vary significantly among the analyzed companies and may cause major economic losses for the productive sector in the region.
\end{abstract}

INDEX TERMS: Wooden breast, white striping, poultry companies, myopathy, slaughterhouse, macroscopic lesions, histopathology lesions.

RESUMO.- [Wooden breast e white striping: ocorrência em três empresas avícolas.] Para melhorar a quantidade de carne produzida, os pesquisadores têm promovido

\footnotetext{
${ }^{1}$ Received on December 14, 2020.

Accepted for publication on February 15, 2021.

${ }^{2}$ Faculdade de Agronomia e Medicina Veterinária, Universidade de Passo Fundo (UPF), Av. Brasil Leste 285, São José, Passo Fundo, RS 99052-900, Brazil.

${ }^{3}$ Laboratório de Patologia e Genômica Animal, Embrapa Suínos e Aves, BR-153 Km 110, Distrito de Tamanduá, Concórdia, SC 89715-899, Brazil.

${ }^{4}$ Centro de Diagnóstico e Pesquisa em Patologia Aviária, Faculdade de Veterinária, Universidade Federal do Rio Grande do Sul (UFRGS), Av. Bento Gonçalves 8824, Porto Alegre, RS 91540-000, Brazil. *Corresponding author: karen.borges@ufrgs.br
}

ao longo dos anos uma seleção genética intensiva para a taxa de crescimento e desenvolvimento de músculos, além de melhorias nas condições nutricionais, sanitárias e de manejo. No entanto, houve um aumento no número de relatos de miopatias dos músculos do peito observados em abatedouros-frigoríficos de aves, incluindo white striping (WS) e wooden breast (WB). 0 objetivo deste estudo foi avaliar a ocorrência de WB e WS em três abatedouros-frigoríficos de aves e realizar uma caracterização anatomopatológica, incluindo análises macroscópicas e microscópicas. Um total de 408.334 carcaças foi condenado (total ou parcialmente) devido à presença WB ou WS, o que representou $0,73 \%$ do 
número total de animais abatidos durante o período avaliado. Apesar de a ocorrência de WB ter sido maior do que a de WS, a frequência de cada uma variou significativamente de acordo com o estabelecimento. WB foi mais frequente no estabelecimento que incluía apenas lotes de machos, com média de 45 dias de idade e peso médio ao abate de $2775 \mathrm{~g}$ (B). WS foi mais frequente no estabelecimento com lotes de machos, fêmeas e mistos, com idade entre 41 e 44 dias e peso médio ao abate entre $1731 \mathrm{~g}-2830 \mathrm{~g}$ (A). Isto pode ser justificado por condições específicas de cada empresa, incluindo genética, idade das aves, nutrição e condições de manejo. Macroscopicamente, as lesões de WB e de WS foram caracterizadas principalmente por hipertrofia e rigidez do músculo pectoralis major. À microscopia, ambas as miopatias mostraram semelhanças em relação às anormalidades histológicas detectadas, caracterizadas principalmente por um processo de miodegeneração. Nos músculos apresentando $\mathrm{WB}$, o infiltrado de tecido conjuntivo foi mais intenso quando comparado àqueles com WS. Os resultados encontrados neste trabalho demonstram que os índices de condenação por essas miopatias são altos, variam significativamente entre as empresas analisadas e podem causar grandes perdas econômicas para o setor produtivo da região.

TERMOS DE INDEXAÇÃO: Wooden breast, white striping, miopatias, abatedouros avícolas, lesões macroscópicas, lesões histopatológicas.

\section{INTRODUCTION}

Brazil is the third largest producer and the main exporter of chicken meat in the world. Over the past several decades, the consumption of chicken meat has increased worldwide, including in Brazil (ABPA 2020). To increase the amount of meat produced, the number of housed birds has been increased. Simultaneously, over the past 50 years, professionals and researchers have promoted intensive genetic selection for growth rate and muscling and have improved nutrition and management conditions (Aviagen 2016). It is estimated that this continuous selection has resulted in nearly a $5 \%$ increase in breast meat, representing more than one-fifth of a broiler's weight (Poultry World 2017). However, these improvements in growth rate and breast muscle size have introduced serious abnormalities that influence the quality of the meat (Huang \& Ahn 2018).

White striping (WS) myopathy is characterized by white striations parallel to the muscle fibers due to fiber degeneration with infiltrated fat (lipidosis) and connective tissue (fibrosis), while wooden breast (WB) is characterized by swollen, hard and rigid muscles surfaces (Kuttappan et al. 2013a, Mazzoni et al. 2015, Mudalal et al. 2015, Huang \& Ahn 2018). The incidence of WS and WB varies widely depending upon researchers, country, and region. Over the past decade, there have been an increasing number of reports of breast muscle myopathies observed in poultry processing plants (Huang \& Ahn 2018, Aviagen 2019). Some of these myopathies, such as WS and WB, have only recently been reported, even though they have been known for some time (Huang \& Ahn 2018). Along with the altered appearance, breast muscles affected by these myopathies display poor technological properties, impaired texture properties, and reduced nutritional value. As consumers have become aware of these abnormalities and concerns for animal welfare have risen, efforts are being made to inhibit the onset of myopathies or alleviate the severity of the symptoms and lesions (Petracci et al. 2019).
Even though these myopathies do not represent a risk to public health, it has been reported that broilers with WS and/or WB cause from $\$ 200$ million to $\$ 1$ billion per year in economic losses to the U.S. poultry industry (Kuttappan et al. 2016, Huang \& Ahn 2018, Barbut 2019). WS has not been associated with any systemic infection, inflammation, or stress conditions, but increased levels of serum creatine kinase (CK), alanine aminotransferase (ALT), aspartate aminotransferase (AST), and lactate dehydrogenase (LDH) have been observed with this myopathy (Kuttappan et al. 2013a). WB, on the other hand, presents with inflammatory characteristics, and the primary inflammatory cells found around the degenerative fiber are macrophages (Huang \& Ahn 2018).

Although the gross and/or histologic characteristics of modern myopathies are similar to those of known conditions such as hereditary muscular dystrophy, nutritional myopathy, toxic myopathies, and marbling, the WS and WB myopathies may have a different basis (Kuttappan et al. 2016). The etiology of these myopathies is not completely elucidated, and several factors are probably associated with their occurrence, including diet, weight gain, and the accelerated growth rate. Factors related to abrupt and massive weight gain favor muscle tissues outgrowing their supporting systems such as connective tissues and capillaries, and they can change the structure and metabolism of the muscle (Huang \& Ahn 2018). Muscle hypertrophy along with the unbalanced growth of supportive connective tissue leads to a compromised blood supply and hypoxia. The associated oxidative stress and mitochondrial dysfunction then leads to lipidosis, fibrosis, and overall myodegeneration (Petracci et al. 2019).

Environmental or management conditions, nutrition, feed additives and genetics are some possible factors that contribute to an increase or an aggravation of these myopathies in certain poultry companies (Moreira et al. 2004, Trocino et al. 2015, Zanetti et al. 2018). The occurrence of these myopathies among Brazilian poultry companies is still not well known. It is within this context that this study aimed to evaluate and to compare the occurrence of WS and WB myopathies in three poultry processing plants and to perform an anatomopathological characterization, including macroscopic and microscopic analyses.

\section{MATERIALS AND METHODS}

Sample characterization. Samples were collected over a period of six months from three poultry slaughterhouses (A, B, and C) located in the state of Rio Grande do Sul (southern Brazil). All the establishments are under the Brazilian Federal Inspection Service and slaughter only broilers of the Cobb lineage. Establishment's characterization, including type of flock, average age and average slaughter weight, is described in Table 1.

Sample collection. During the evisceration process, carcasses that presented with hypertrophy and stiffness of the chest region were separated for the "Departamento de Inspeção Final" (DIF) (Brasil 1998) by trained employees on the inspection lines. As previously described (Kuttappan et al. 2012a, 2013a, Sihvo et al. 2014, Mudalal et al. 2015, Cruz et al. 2017), the presence of WS or WB was determined by trained professionals in the DIF based on their visualization of macroscopic lesions. Liver fragments were also collected from all carcasses for microscopic analyses.

Anatomopathological and histopathological characterization. The carcasses were classified according to the type of injury (WB 
or WS) following characterization standards previously described in the literature (Kuttappan et al. 2012a, 2013a, Sihvo et al. 2014, Mudalal et al. 2015, Cruz et al. 2017). The apparent macroscopic changes observed externally in the carcasses were confirmed by cutting the pectoralis major muscle. After the macroscopic analysis, $1.5 \mathrm{~cm}^{2}$ fragments of the pectoralis major muscle were collected for histopathological analysis. Ten fragments of each myopathy and three additional samples from the same flock without apparent macroscopic lesions (control group) were collected. Liver samples were collected from all carcasses to evaluate whether a relationship existed between the severities of the breast and liver lesions. Samples were fixed in $10 \%$ buffered formalin and sent to the laboratory of "Embrapa Suínos e Aves" (Brazilian Agricultural Research Corporation, Ministry of Agriculture, Livestock and Supply) for histopathological analysis. The materials were routinely processed and stained with hematoxylin and eosin (HE). Some paraffin-embedded tissues were selected and stained with Masson's trichrome stain, which is widely used to study muscular pathologies and allows for the quantitative visualization and analysis of collagen fibers in connective tissue (Street et al. 2014). Lesions in the breast and liver were classified according to their severity: no lesion or mild, moderate, and severe lesions.

Statistical analysis. Descriptive statistics were used to calculate the absolute and relative frequencies of the WB and WS myopathies and liver lesions according to their severity. Chi-Square $\left(\chi^{2}\right)$ and Fisher exact tests were used to examine the proportion of lesions among the companies and the association of WB or WS with liver lesions. Statistical testing was performed with SPSS software (Statistical Package for Social Sciences) with a 5\% level of significance.

\section{RESULTS}

\section{Occurrence of wooden breast and white striping}

A total of 55,839,154 birds were slaughtered in the three establishments during the observation period: 25,728,260 (46.08\%) in Establishment A, 26,015,695 (46.59\%) in Establishment B, and 4,095,199 (7.33\%) in Establishment C. A total of 408,334 $(0.73 \%)$ of the slaughtered birds were condemned for WS or WB myopathies. Of these, $74.94 \%(306,005)$ were affected with WB and $25.06 \%(102,329)$ with WS. Table 1 shows the occurrence rates for WB and WS according to each establishment.

Establishment $\mathrm{B}$ had the highest rate of total condemnations $(p<0.05)$, and most (79.44\%) were for WB lesions $(p<0.05)$. Establishment A was the main responsible (70.94\%) for WS condemnations $(p<0.05)$. Finally, Establishment $C$, which had the least number of carcasses processed during the period, had lower rates of condemnation.

\section{Macroscopic characterization}

Wooden breast. The analysis of the breasts with WB myopathy showed that the lesions could be unilateral or bilateral. The affected breasts had slightly pale skin in comparison to those without apparent macroscopic lesions (Fig.1A-D). When cutting the skin, a fluid (color ranging from translucent to yellowish) with a gelatinous aspect was observed on the ventral surface of the pectoralis major muscle. It was also observed the presence of a thick, white mass covering the ventral surface of the pectoralis major muscle (Fig.1E). Some carcasses also showed white stripes similar to those observed in the WS cases. Lesions similar to those of WB were observed in the gastrocnemius muscle (Fig.1F). Muscle hypertrophy and a pale to yellowish color were also observed in the breasts, mainly in the caudal region. Muscle hypertrophy was also observable after cutting the breasts. In rare cases, hemorrhage was found among the fibers. Some breasts also had white striations, but they were not parallel to the direction of the fibers.

White striping. The analysis of the breasts with WS myopathy indicated unilateral and bilateral lesions. The skin of the breasts affected by WS was slightly reddish, and blood vessel thickening could be observed. After cutting the breast, the carcasses had translucent to yellowish fluid with a gelatinous aspect on the ventral surface of the pectoralis major muscle. In addition to the white stripes, there were cases of superficial hemorrhage and muscles with a firmer consistency than muscles without apparent macroscopic lesions. Upon cutting, the muscle hypertrophy was observable. Rare cases of hemorrhage were also found among the fibers (Fig.2).

\section{Microscopic characterization}

Control group. The pectoralis major muscle of the controls showed bundles of muscle fibers of uniform size and shape, with visible transversal striations. Lymphocytes cells infiltrate, a few adipose cells, and mild interstitial connective tissue hyperplasia were also observed.

Wooden breast. The degenerative lesions of the muscle fibers presented interstitial connective tissue, inclusion of adipose tissue, cellular debris, and infiltrated of heterophilic and lymphocytes cells. Perivascular inflammatory cell infiltrate could also be seen in some fragments. The degenerative lesions were classified as moderate or severe according to the magnitude and scope of the microscopic lesions. The lesions were considered moderate when some of the myofibers of the analyzed fragment showed hyaline degeneration with hyper-eosinophilic fibers and a loss of

Table 1. Occurrence of white striping (WS) and wooden breast (WB) at three slaughterhouses in southern Brazil

\begin{tabular}{|c|c|c|c|c|c|c|}
\hline Establishment & Type of flock & Average age & Average weight & $\begin{array}{c}\text { Total } \\
\text { (WS or WB) }\end{array}$ & WS & WB \\
\hline $\mathrm{A}$ & Female & 34 days & $1731 \mathrm{~g}$ & & & \\
\hline B & Male & 45 days & $2775 \mathrm{~g}$ & $246,860(60.46 \%)^{\mathrm{b}}$ & $3,766(3.68 \%)^{b}$ & $243,094(79.44 \%)^{\mathrm{b}}$ \\
\hline \multirow[t]{2}{*}{$\mathrm{C}$} & Male & 44 days & $2732 \mathrm{~g}$ & $58,922(14.43 \%)^{\mathrm{a}}$ & $25,971(25.38 \%)^{c}$ & $32,951(10.77 \%)^{\mathrm{a}}$ \\
\hline & Female & 45 days & $2420 \mathrm{~g}$ & & & \\
\hline TOTAL & & & & 408,334 & 102,329 & 306,005 \\
\hline
\end{tabular}

$\overline{\mathrm{a}, \mathrm{b}, \mathrm{c}}$ Distinct letters in the same column indicate statistically significant difference $(p<0.05)$ 

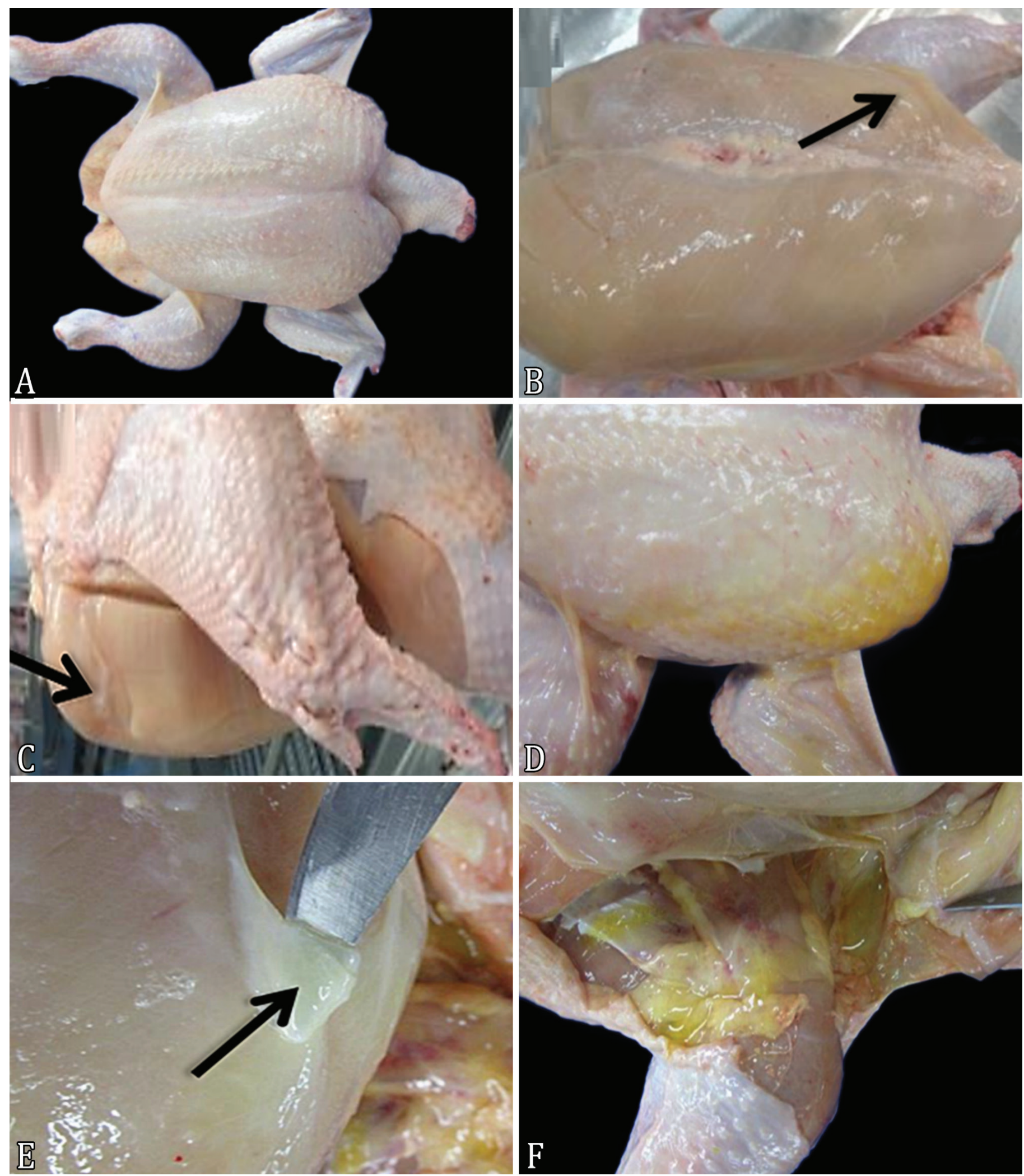

Fig.1. Carcasses presenting wooden breast (WB) lesions. (A) Control: broiler carcass without macroscopic changes. (B) WB lesions: presence of a thin layer of serous fluid, pale and stiff areas and a marked hypertrophy on the ventral surface, mainly in the caudal left region (arrow) of the pectoralis major muscle. (C) WB lesion: lesion located mainly in the cranial portion of the pectoralis major muscle, presence of a thin pale membrane on the ventral surface of the muscle (arrow). (D) WB lesions: severe lesion with edema, thickening and yellow discoloration of the skin, mainly in the cranial left region of the pectoralis major muscle. (E) Presence of a thick, white mass (arrow) covering the ventral surface of the pectoralis major muscle. (F) Presence of a lesion similar to WB lesions, but in the gastrocnemius muscle, with the presence of petechiae on the muscle surface. 
transversal striations. When the majority of the myofibers showed hyaline to floccular degeneration and necrosis, the lesion was considered severe (Fig.3). In these cases, abundant interstitial connective tissue, cellular debris, lymphocytes and sometimes heterophiles infiltrates were observed along with the adipose tissue, compromising the entire tissue interstitium. After classification, $60 \%$ (18/30) of the lesions were rated severe, and $40 \%(12 / 30)$ were moderate. There was no significant difference $(p>0.05)$ in the occurrence of WB among the three establishments evaluated, regardless of the degree of lesions in the pectoralis major muscle.
White striping. Sample fragments from breast meat with WS presented interstitial connective tissue, cellular debris, and lymphocytes and heterophilic cell infiltrates. Infiltrated adipose tissue was detected in all fragments analyzed and was relatively abundant. In some fragments, it was also possible to observe perivascular inflammatory cell infiltrate. Degenerative muscle fiber lesions were classified as moderate (Fig.4A) or severe (Fig.4B). The lesions were considered moderate when the observations included tumefied fibers and the interstitial infiltration of loose connective tissue, adipose tissue, sparse mononuclear cells (lymphocytes), and
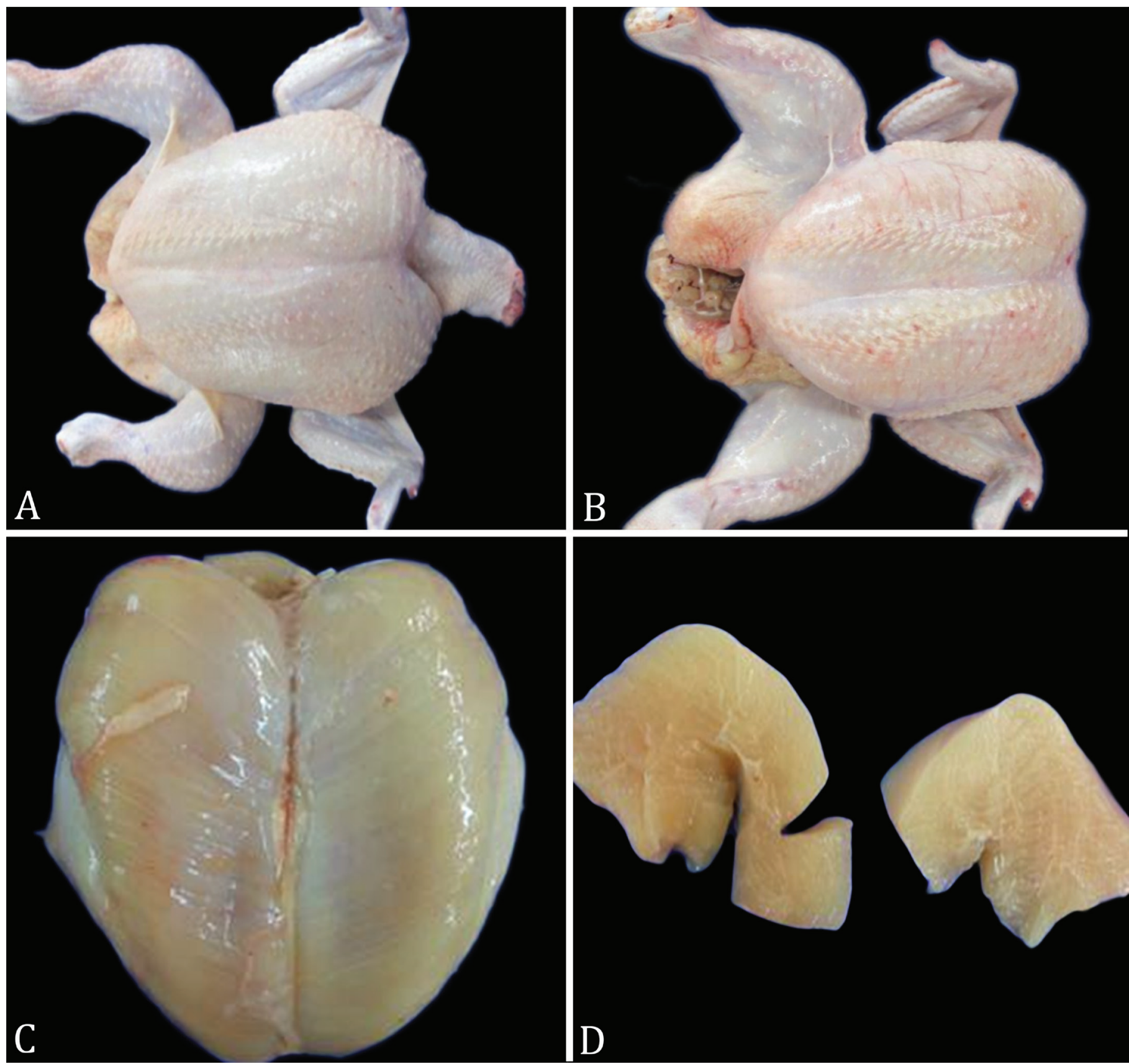

Fig.2. Carcasses presenting white striping (WS) lesions. (A) Control: broiler carcass without macroscopic changes. (B) WS lesions: hypertrophy and stiffness in the cranial portion of the pectoralis major muscle and a slight change in the color of the skin and blood vessels in the region. (C) White stripes in parallel to the muscle fibers, a ventral view of the breast. (D) White stripes and muscle hypertrophy observed after transverse section. 
cellular debris. In severe lesions, most myofibers exhibited degeneration (ranging from hyaline to floccular) and an abundant interstitial infiltration of adipose and connective tissues. Cellular debris and lymphocytes and heterophilic infiltrates were also detected in these cases. The severe lesions corresponded to $36.7 \%(11 / 30)$ of the WS lesions, while $33.3 \%(10 / 30)$ were moderate. Fragments with no lesions, $20 \%$ (6/30), and slight lesions, $10 \%$ (3/30), were also observed. There was no significant difference $(p>0.05)$ in the occurrence of WS among the three establishments evaluated, regardless of the lesion degree in the pectoralis major muscle.

Livers. Histological findings in the livers ranged from no lesions to mild or moderate lesions. A lesion was considered mild when the parenchyma had sparse foci of hepatocyte degeneration and lymphoid follicle hyperplasia. The lesion was classified as moderate when degenerate hepatocyte foci with well-defined vacuoles, congestion, and lymphoid follicle hyperplasia were observed. There was no significant difference
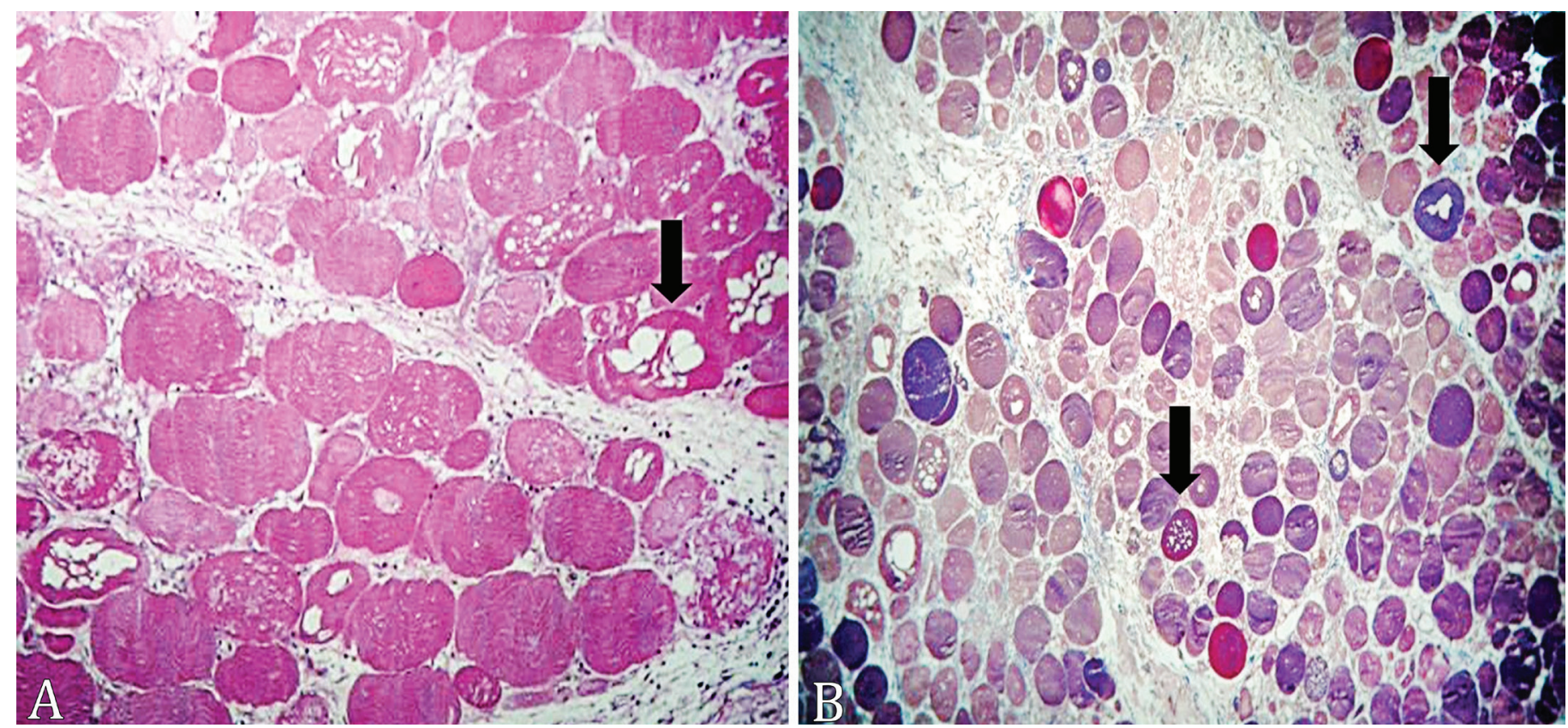

Fig.3. Severe wooden breast lesions in the pectoralis major muscle. (A) Muscle fibers in several stages of degeneration and fiber with vacuolization (arrow), transverse section. HE, obj.40x. (B) Muscle fibers in different stages of degeneration (arrow), transverse section. Masson's trichrome, obj.10x.
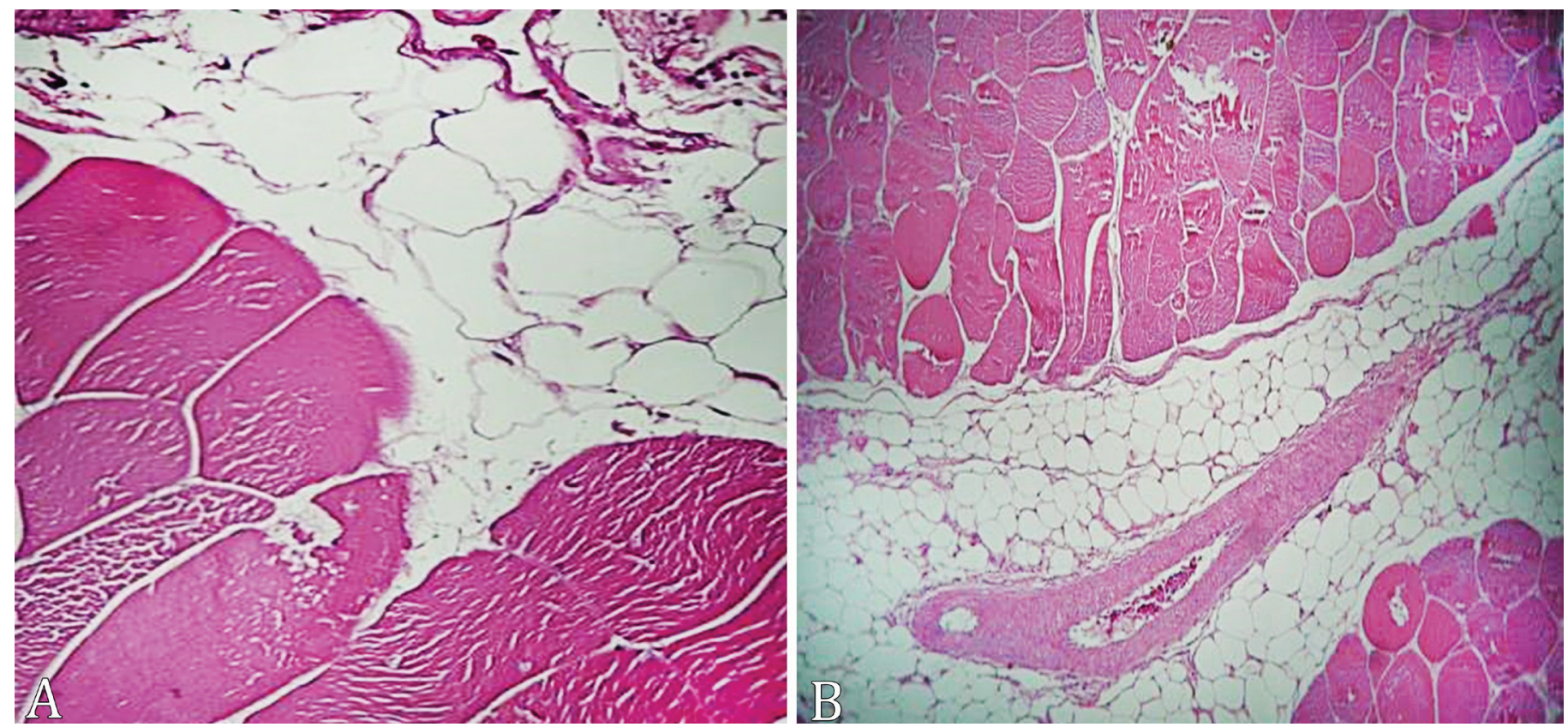

Fig.4. Sections of the pectoralis major muscle with white striping lesions. Presence of interstitial adipose tissue in (A) moderate lesion, transverse section, and (B) severe lesion, transverse section. (A) HE, obj.40x. (B) HE, obj.10x. 
$(p>0.05)$ in the occurrence of histopathological alterations among the three establishments evaluated, regardless of the degree of liver lesions. Furthermore, there was no association $(p>0.05)$ between the presence or degree of injury observed in the pectoralis major muscle and in the liver of the respective carcass, regardless of the establishment evaluated.

\section{DISCUSSION}

In this study, a total of 408,334 carcasses were condemned or downgraded due to the presence of WB or WS, which represented $0.73 \%$ of the total number of slaughtered animals during the evaluated period. As the selection of carcasses for inspection in the DIF was performed by the official inspection service during the routine slaughter process, it is possible that carcasses with an initial degree of myopathy, but no evident lesions, were not been identified. In total, the majority (74.94\%) of affected carcasses were due to WB myopathy, while a smaller number (25.06\%) were for WS. The occurrence of WS and WB among all myopathies can vary from $1 \%$ to $75 \%$ depending on the establishment, the region, and the country (Kuttappan et al. 2009, 2012a, 2013a, Owens 2014, Trocino et al. 2015, Gratta et al. 2017, Huang \& Ahn 2018, Malila et al. 2018). Although information on the occurrence of these myopathies is limited, and at times contradictory, it is assumed that chicken breasts with abnormalities appear in all countries where fast-growing hybrids are used and that the number is higher than the chicken industry would care to admit (Petracci et al. 2019).

WB and WS were more frequently in Establishments B (79.44\%) and A (70.94\%), respectively. Since WB is strongly associated with carcasses from heavier birds (Norring et al. 2018), the higher occurrence of this myopathy in Establishment $B$, which slaughters only heavier birds and male flocks, would be expected. Kuttappan et al. (2013a) also observed a difference in the occurrence of myopathies associated with the live weight of broilers. In addition to a correlation with slaughter body weight, WB is also a consequence of the age of the birds. In general, the flocks in Establishment B were older. These lesions are more frequent in broilers after 21 days of age, when the growth rate is higher. During this period, more than $50 \%$ of the birds can develop WB (Owens 2014). Bauermeister et al. (2009) also reported a higher occurrence of WB in broilers processed at an older (8-weeks old) rather than younger age (6-weeks old), presumably due to the greater body weight of the older birds. Histological observations have confirmed that the myodegeneration process associated with the development of breast abnormalities is strictly related to age at slaughter and is higher in males (Kuttappan et al. 2013a, Trocino et al. 2015, Sihvo et al. 2017). Differences in the feed composition used by different companies could also be a reason for the variation in rates of WS and WB (Huang \& Ahn 2018). High-energy diets and the associated increased levels of lipid production increase the occurrence of WS in breast fillets (Kuttappan et al. 2009), as was especially observed in Establishment A.

During the evaluation of the carcasses in this study, a significant number $(5,770 ; 1.89 \%)$ presented with the dorsal cranial myopathy (DCM) lesions in association with WB. Most of these were detected in Establishment A (60.05\%), followed by Establishments B (33.66\%) and C (6.29\%). There are still no studies on a possible relationship between DCM and WB lesions in chicken breasts. However, both myopathies are associated with heavier birds and with rapid growth rates (Zimermann et al. 2012, Sihvo et al. 2014). In rare cases (one in Establishment A and one in Establishment C), carcasses with WB and deep pectoral myopathy were also found in this study.

The macroscopic lesions in our study were similar to those of previous studies (Kuttappan et al. 2012a, 2016, Velleman \& Clark 2015). The lesions of both myopathies were characterized by hypertrophy and stiffness of the pectoralis major and gastrocnemius muscles. In the WB lesions, there was noticeable bulging of the fillets, mainly in the caudal region. This caudal location differs from that described by Zotte et al. (2017), who reported WB abnormalities that were primarily localized in the cranial portion of the fillet. It is important to highlight that the occurrence of fibrosis in WB myopathy, especially in the severe cases described in this study, may not necessarily affect the texture properties of the breast (Sihvo et al. 2017), and that detection of this myopathy by palpation may be an intricate task (Petracci et al. 2019). However, some birds showed markedly hardened breast musculature with no histologically apparent fibrosis, indicating that fibrosis is not the sole factor behind the hardness of $\mathrm{WB}$ and that the lesions are not restricted to the pectoralis major muscle (Huang \& Ahn 2018).

On microscopy, the breast fragments affected by WB and WS were similar regarding the histological abnormalities detected and characterized mainly by a process of myodegeneration. However, compared to the WS group, the connective tissue infiltrate in the WB group was more intense, affecting both the endomysium and perimysium. Generally, highest levels of fibrosis are observed in WB myopathy (Trocino et al. 2015), and the fibrotic changes in this myopathy can also vary between different broiler lines (Velleman et al. 2014, Velleman \& Clark 2015). In contrast, despite the replacement of muscle fibers with fibrous connective tissue (fibrosis) in fragments from the WS group, the interstitial infiltrate of adipose tissue was more evident, and generally occurred only in the perimysium. An accumulation of adipose tissue (lipidosis) is one of the major histologic changes associated with WS, which also includes fiber necrosis, the degeneration and regeneration of fibers of variable size, a loss of cross striations, the mineralization of nuclei, and hyalinization (Sihvo et al. 2014, Russo et al. 2015). Other studies have also shown similar histologic changes in the muscles affected by WS and WB (Kuttappan et al. 2009, Sihvo et al. 2014, 2017), which may reinforce the hypothesis of a common etiology for these myopathies. However, Sihvo et al. (2014) observed that fillets with WB were affected by an inflammatory process, as demonstrated by the presence of T lymphocytes, which was not seen in the WS cases (Kuttappan et al. 2013a). One possibility is that WS occurs during the initial phase of muscle degeneration, while WB occurs at a later stage of development (Mudalal et al. 2015).

Previous studies have shown that some myopathies are related to changes in serum enzyme levels in broilers (Kuttappan et al. 2013b, Sesterhenn et al. 2017). In these cases, concentrations of the enzymes ALT, AST, CK, and LDH were increased (Kuttappan et al. 2013b). These plasmatic enzymes changes can indicate hepatic damage or damage in the skeletal muscles of the broilers (MacRae et al. 2006, Yan et al. 2009). This is why the livers of the carcasses affected with WB and WS were also analyzed, to look for a possible 
relationship between the lesions present in the muscle with those found in the liver. However, no relationship was found between the severity of the microscopic changes in the pectoralis major muscle and the liver lesions. It probably suggests that the enzyme elevations are primarily due to the muscle degeneration rather than liver damage.

Chicken meat consumption has increased worldwide, which is mainly attributable to its relatively low cost and nutritional properties (Estévez 2015, Wideman et al. 2016, Petracci et al. 2019). However, lesions in poultry meat have led to economic losses within the industry, especially due to WS and WB (Huang \& Ahn 2018, Zanetti et al. 2018). Once WS and WB impair the appearance and functional quality of breast meat (Huang \& Ahn 2018), affected breast fillets are often downgraded and sold at a discount, used for further processing, or even discarded (Baltic et al 2019). The notable discolorations on the skin-side surfaces of severe WB fillets after cooking and the white striations on the ventral surfaces of raw WS fillets negatively impacts the purchasing decisions of consumers (Huang \& Ahn 2018). Over 50\% of consumers have indicated they would not buy WS and WB fillets (Kuttappan et al. 2012b).

In Brazil, there is no legislation regarding carcass condemnation due to these myopathies. In any case, both the federal inspection service and the poultry companies have the responsibility of preventing the commercialization of breast fillets from birds affected by WS or WB myopathy. Specific legislation would allow for these cuts to be commercialized as alternative products (Zanetti et al. 2018). A previous study in the same region of Southern Brazil showed that WS and WB could be responsible for losses of up to US $\$ 17,962.56$ per year in a single establishment with a similar occurrence $(0.8 \%)$ of these myopathies (Zanetti et al. 2018). With the exception of breast fillets sold with skin, two of the three companies in this study target all slaughtered poultry for cutting. However, one of the companies analyzed sells whole carcasses, which increases the likelihood of affected birds reaching consumers' tables. As consumer awareness on the presence and origin of these chicken defects is increasing, transforming abnormal breasts into processed chicken products may be a feasible option. However, a means of improving breast meat's technological, sensory, and nutritional properties are also required (Petracci et al. 2019).

\section{CONCLUSIONS}

White striping (WS) or wooden breast (WB) myopathies were detected in $0.73 \%$ of the slaughtered animals. WB lesions were majoritarian found in establishments that slaughter male flocks and WS was more frequent in establishments that slaughter male, female and mixed flocks.

Under microscopy, the myopathies showed similarities regarding the detected histological abnormalities, although the connective tissue infiltrate was more evident in the breasts with WB.

There was no relation between liver and muscle lesions, regardless the myopathy and the poultry company.

The results found in this study demonstrate that the rates of condemnation for these myopathies are high, vary significantly among the analyzed companies and may cause major economic losses for the productive sector in the region.
Acknowledgements.- The authors thank the teams of the "Laboratório de Patologia Animal" of the "Universidade de Passo Fundo" and the "Laboratório de Patologia e Genômica Animal" of "Embrapa Suínos e Aves". They also thank the administrative managers of the three companies involved, the SIF and MAPA/SIPOA/RS for their understanding of the need and importance of this project, in addition to the availability of professionals to carry out the experiments.

Conflict of interest statement.- The authors have no competing interests.

\section{REFERENCES}

ABPA 2020. Relatório Anual 2020. Associação Brasileira de Proteína Animal, São Paulo. Available at <https://abpa-br.org/relatorios> Accessed on Oct. 21, 2020.

Aviagen 2016. Ross 308 broiler: performance objectives. Available at <http:// en.aviagen.com/assets/Tech_Center/Ross_PS//Ross308-PS-PO-EN-2016. pdf> Accessed on Mar. 30, 2020.

Aviagen 2019. Breast muscles myopathies. Available at <http://eu.aviagen. com/tech-center/download/1282/Breast-Muscle-Myopathies-2019-EN.pdf> Accessed on Mar. 30, 2020.

Baltic M., Rajcic A., Laudanovic M., Nesic S., Baltic T., Ciric J. \& Lazic I.B. 2019. Wooden breast: a novel myopathy recognized in broiler chickens. 60th International Meat Industry Conference (MEATCON2019), IOP Conference Series: Earth and Environmental Science, Kopaonik Mountain, Serbia, 333:012037. <https://dx.doi.org/10.1088/1755-1315/333/1/012037>

Barbut S. 2019. Recent myopathies in broiler's breast meat fillets. World Poult. Sci. J. 75(4):559-582. <https://dx.doi.org/10.1017/S0043933919000436>

Bauermeister L.J., Morey A.U., Moran E.T., Singh M., Owens C.M. \& McKee S.R. 2009. Occurrence of white striping in chicken breast fillets in relation to broiler size. Poult. Sci. 88(33 Supl.1):33.

Brasil 1998. Portaria 210: Regulamento Técnico da Inspeção Tecnológica e Higiênico-Sanitária de Carne de Aves. Ministério da Agricultura Pecuária e Abastecimento. Available at <https://www.gov.br/agricultura/pt-br/ assuntos/inspecao/produtos-animal/empresario/arquivos/Portaria2101998. pdf/view $>$ Accessed on Mar. 30, 2020.

Cruz R.F., Vieira S.L., Kindlein L., Kipper M., Cemin H.S. \& Rauber S.M. 2017. Occurrence of white striping and wooden breast in broilers fed grower and finisher diets with increasing lysine levels. Poult. Sci. 96(2):501-510. <https://dx.doi.org/10.3382/ps/pew310><PMid:27655901>

Estévez M. 2015. Oxidative damage to poultry: from farm to fork. Poult. Sci. 94(6):1368-1378. <https://dx.doi.org/10.3382/ps/pev094><PMid:25825786>

Gratta F., Birolo M., Piccirillo A., Petracci M., Maertens L., Xiccato G. \& Trocino A. 2017. Effects of the feeding system on performance and myopathy occurrence in two broiler chicken genotypes. Ital. J. Anim. Sci. 16:48.

Huang X. \& Ahn D.U. 2018. The incidence of muscle abnormalities in broiler breast meat, a review. Korean J. Food Sci. Anim. 38(5):835-850.<https:// dx.doi.org/10.5851/kosfa.2018.e2 > <PMid:30479493>

Kuttappan V.A., Brewer V.B., Clark F.D., Mckee S.R., Meullenet J.F., Emmert J.L. \& Owens M.C. 2009. Effect of white striping on the histological and meat quality characteristics of broiler fillets. Poult. Sci. 88(447):136-137.

Kuttappan V.A., Goodgame S.D., Bradley C.D., Mauromoustakos A., Hargis B.M., Waldroup P.W. \& Owens C.M. 2012a. Effect of different levels of dietary vitamin $\mathrm{E}$ (DL- $\alpha$-tocopherol acetate) on the occurrence of various degrees of white striping on broiler breast fillets. Poult. Sci. 91(12):3230-3235. <https://dx.doi.org/10.3382/ps.2012-02397><PMid:23155035>

Kuttappan V.A., Hargis B.M. \& Owens C.M. 2016. White striping and woody breast myopathies in the modern poultry industry: a review. Poult. Sci. 95(11):2724-2733. <https://dx.doi.org/10.3382/ps/pew216> <PMid:27450434> 
Kuttappan V.A., Huff G.R., Huff W.E., Hargis B.M., Apple J.K., Coon C. \& Owens C.M. 2013b. Comparison of hematologic and serologic profiles of broiler birds with normal and severe degrees of white striping in breast fillets. Poult. Sci. 92(2):339-345. <https://dx.doi.org/10.3382/ps.2012-02647> $<$ PMid:23300298>

Kuttappan V.A., Lee Y.S., Erf G.F., Meullernet J.F., McKee S.R. \& Owens C.M. 2012b. Consumer acceptance of visual appearance of broiler breast meat with varying degrees of white striping. Poult. Sci. 91(5):1240-1247. <https://dx.doi.org/10.3382/ps.2011-0194><PMid:22499884>

Kuttappan V.A., Shivaprasad H.L., Shaw D.P., Valentine B.A., Hargis B.M., Clark F.D., Mckee S.R. \& Owens C.M. 2013a. Pathological changes associated with white striping in broiler breast muscles. Poult. Sci. 92(2):331-338. <https://dx.doi.org/10.3382/ps.2012-02646> <PMid:23300297>

MacRae V.E., Mahon M., Gilpin S., Sandercock D.A. \& Mitchell M.A. 2006. Skeletal muscle fibre growth and growth associated myopathy in the domestic chicken (Gallus domesticus). Poult. Sci. 47(3):264-272. <https://dx.doi.org/10.1080/00071660600753615><PMid:16787849>

Malila Y., U-chupaj J., Srimarut Y., Chaiwiwattrakul P., Uengwetwanit T., Arayamethakorn S., Punyapornwithaya V., Sansamur C., Kirschke C.P., Huang L., Tepaamorndech S., Petracci M., Rungrassamee W. \& Visessanguan W. 2018. Monitoring of white striping and wooden breast cases and impacts on quality of breast meat collected from commercial broilers (Gallus gallus). Asian-Australas J. Anim Sci. 31(11):1807-1817. <https://dx.doi.org/10.5713/ajas.18.0355><PMid:30145875>

Mazzoni M., Petracci M., Meluzzi C., Cavani P., Clavenzani A. \& Sirri F. 2015. Relationship between Pectoralis major muscle histology and quality traits of chicken meat. Poult. Sci. 94(1):123-130.<https://dx.doi.org/10.3382/ ps/peu043><PMid:25577799>

Moreira J., Mendes A.A., Roça R.O., Garcia E.A., Naas I.A., Garcia R.G. \& Paz I.C.L.A. 2004. Efeito da densidade populacional sobre desempenho, rendimento de carcaça e qualidade da carne em frangos de corte de diferentes linhagens comerciais. Revta Bras. Zootec. 33(6):1506-1519. <https://dx.doi.org/10.1590/S1516-35982004000600018>

Mudalal S., Lorenzi M., Soglia F., Cavani C. \& Petracci M. 2015. Implications of white striping and wooden breast abnormalities on quality traits of raw and marinated chicken meat. Animal 9(4):728-734. <https://dx.doi. org/10.1017/S175173111400295X > <PMid:25500004>

Norring M., Valros A., Valaja J., Sihvo H.K., Immonen K. \& Puolanne E. 2018. Wooden breast myopathy links with poorer gait in broiler chickens. Animal. 17:1-6. <https://dx.doi.org/10.1017/S1751731118003270> $<$ PMid:30556797>

Owens C.M. 2014. Identifying quality defects in poultry processing. Watt Poultry USA, p.42-50.

Petracci M., Soglia F., Madruga M., Carvalho L., Ida E. \& Estévez M. 2019. Wooden-breast, white striping, and spaghetti meat: causes, consequences and consumer perception of emerging broiler meat abnormalities. Compr. Rev. Food Sci. Food Saf. 18(2):565-583. <https://dx.doi.org/10.1111/15414337.12431>

Poultry World 2017. White striping and woody breast myopathies. Available at<https://www.poultryworld.net/Meat/Articles/2017/4/White-stripingand-woody-breast-myopathies-124372E/> Accessed on Mar. 30, 2020.

Russo E., Drigo M., Longoni C., Pezzoti R., Fasoli P. \& Recordati C. 2015. Evaluation of white striping prevalence and predisposing factors in broilers at slaughter. Poult. Sci. 94(8):1843-1848. <https://dx.doi.org/10.3382/ ps/pev172><PMid:26112037>

Sesterhenn R., Siqueira F.M., Hamerski A.C., Driemeier D., Valle S.F., Vieira S.L., Kindlein L. \& Nascimento V.P. 2017. Histomorphometric study of the Anterior Latissimus Dorsi muscle and evaluation of enzymatic markers of broilers affected with dorsal cranial myopathy. Poult. Sci. 96(12):42174223. <https://dx.doi.org/10.3382/ps/pex252>

Sihvo H.K., Immonen K. \& Puolanne E. 2014. Myodegeneration with fibrosis and regeneration in the pectoralis major muscle of broilers. Vet. Pathol. 51(3):619-623. <https://dx.doi.org/10.1177/0300985813497488> $<$ PMid:23892375>

Sihvo H.K., Lindén J., Airas N., Immonen K., Valaja J. \& Puolanne E. 2017. Wooden breast myodegeneration of Pectoralis major muscle over the growth period in broilers. Vet. Pathol. 54(1):119-128. <https://dx.doi. org $/ 10.1177 / 0300985816658099><$ PMid:27511311>

Street J.M., Souza A.C.P., Alvarez-Prats A., Horino T., Hu X., Yuen P.S.T. \& Star R.A. 2014. Automated quantification of renal fibrosis with sirius red and polarization contrast microscopy. Physiol. Rep. 2(7):e12088. <https://dx.doi.org/10.14814/phy2.12088><PMid:25052492>

Trocino A., Piccirillo A., Birolo M., Radaelli G., BertottoD., Filiou E., Petracci M. \& Xiccato G. 2015. Effect of genotype, gender and feed restriction on growth, meat quality and the occurrence of white striping and wooden breast in broiler chickens. Poult. Sci. 94(12):2996-3004. <https://dx.doi. org/10.3382/ps/pev296><PMid:26475069>

Velleman S.G. \& Clark D.L. 2015.Histopathologic and myogenic gene expression changes associated with wooden breast in broiler breast muscles. Avian Dis. 59(3):410-418. <https://dx.doi.org/10.1637/11097-042015-Reg.1> $<$ PMid:26478160>

Velleman S.G., Coy C.S. \& Emmerson D.A. 2014. Effect of the timing of posthatch feed restrictions on the deposition of fat during broiler breast muscle development. Poult. Sci. 93(10):2622-2627. <https://dx.doi.org/10.3382/ ps.2014-04206><PMid:25085937>

Wideman N., O’Bryan C.A. \& Crandall P.G. 2016. Factors affecting poultry meat colour and consumer preferences: a review. World Poult. Sci. J. 72(2):353366. <https://dx.doi.org/10.1017/S0043933916000015>

Yan J., Bao E. \& Yu J. 2009. Heat shock protein 60 expression in heart, liver and kidney of broilers exposed to high temperature. Res. Vet. Sci. 86(3):533538. <https://dx.doi.org/10.1016/j.rvsc.2008.09.002><PMid:18951595>

Zanetti M.A., Tedesco D.C., Schneider T., Teixeira S.T.F., Daroit L., Pilotto F., Dickel E.L., Santos S.P. \& dos Santos L.R. 2018. Economic losses associated with Wooden Breast and White Striping in broilers. Semina, Ciênc. Agrárias 39(2):887-892.<https://dx.doi.org/10.5433/1679-0359.2018v39n2p887>

Zimermann F.C., Fallavena L.C.B., Salle C.T.P., Moraes H.L.S., Soncini R.A., Barreta M.H. \& Nascimento V.P. 2012. Downgrading of heavy broiler chicken carcasses due to myodegeneration of the Anterior latissimus dorsi: pathologic and epidemiologic studies. Avian Dis. 56(2):418-421. <https://dx.doi.org/10.1637/9860-072111-Case.1><PMid:22856205>

Zotte A.D., Tasoniero G., Puolanne E., Remignon H., Cecchinato M., Catelli E. \& Cullere M. 2017. Effect of "Wooden Breast" appearance on poultry meat quality, histological traits, and lesions characterization. Czech J. Anim. Sci. 62(2):51-57. <https://dx.doi.org/10.17221/54/2016-CJAS> 